\title{
General Medical Services Committee
}

The General Medical Services Committee met on 5 August, with Dr. F. C. Cameron in the chair. A report of the Committee's debate on developments in the negotiations with the Minister of Health on the Charter for the Family Doctor Service since the Annual Represenative Meeting at Swansea was printed last week (Supplement, 14 August, p. 115). We print below a report of the remainder of the Committee's proceedings.

\section{Labelling of Containers}

Dr. S. Noy ScotT reported that it was indicated at a joint meeting of representatives of the Pharmaceutical Society and the B.M.A. the previous day that the letters "N.P." would be acceptable to pharmacists, provided the letters were used in relation to each individual item on a form where appropriate, that they were written, and it was understood that the name written on the prescription was that written on the label. The pharmacists had also tentatively agreed that they would put on the strength in the case of tablets and capsules where considered appropriate.

\section{General Practice Advisory Service}

The Committee appointed the following working group to investigate the possibility of active general practitioners being appointed as advisers in general practice on a regional or area basis: Drs. B. Cardew, A. B. Gilmour, J. S. Happel, E. V. Kuenssberg, F. Lishman, R. B. L. Ridge, and A. J. Rowe.

\section{Improvement Grants}

The Committee considered a draft letter to executive councils dealing with the Improvements Grants Scheme, together with comments made by the Association's Solicitor and after making certain amendments agreed that the document be discussed with the Ministry's representatives.

\section{Constitution of the Committee}

The Committee received the following resolution passed by the Lancashire Local Medical Committee: "That this Committee is perturbed that little or no action has been taken on the resolution passed at the 1964 Annual Conference in connexion with the constitution of the General Medical Services Committee."

Dr. A. B. Gilmour suggested that the procedure of the Committee required even more urgent attention than its constitution. The Committee had been faced at the beginning of the day with documents totalling just under 300 pages with which to deal. There was a danger of the work load of the Committee making it grind to a halt. Detailed regulations and such like should in his view receive unhurried consideration by members experienced in that field, and their reports should be available for approval by the Committee. Working groups which did a great deal of preparatory work should be reorganized, and authority to look into routine matters should be delegated. At the moment too much was left on the shoulders of all too few.
The Chairman said that the Committee would do all it possibly could to delegate some of the work. Much of the trouble on the present occasion had been that a great deal of the work had not been foreseen.

\section{Medical Practices Committee}

The Committee received from the Medical Practices Committee statistics for the quarter ended 30 June which showed that the names of 295 general practitioners had been deleted from the National Health Service medical list during the quarter and that 232 names had been added. There were therefore 63 fewer doctors on the medical list at the end of the quarter than at the beginning. Figures for the corresponding quarter in 1964 were 258 names deleted and 270 added-an increase of 12 .

The number of advertised practice vacancies dealt with by the Medical Practices Committee in the quarter ended 30 June was 72 (50 in the corresponding quarter in 1964) and the number of applications was 581 (495 in 1964).

The average number of applications per practice vacancy was 8.2 , compared with 9.9 in 1964

The Committee also considered a memorandum on designated areas prepared by the Medical Practices Committee. A tribute was paid to the staff of the Medical Practices Committee for their work in compiling the memorandum, which the Committee agreed to send to the Working Group on Inducements in Special Areas, and for preparing the quarterly statistical return.

The remainder of the business was deferred and the meeting terminated at 7.20 p.m.

\section{Association Notices}

\section{Elections to Public Health Committee 1965-6}

The Annual Representative Body has approved a revised constitution for the Public Health Committee of the British Medical Association which will include the appointment of nine members elected by regional constituencies. These constituencies will be based on the Regional Offices of the B.M.A. in the following manner :

\begin{tabular}{|c|c|c|c|c|c|}
\hline \multicolumn{6}{|c|}{ Constituency } \\
\hline A & & $\cdots$ & $\cdots$ & $\cdots$ & Scotland, one seat \\
\hline B & $\ldots$ & $\cdots$ & & $\ldots$ & e one seat \\
\hline C & $\cdots$ & $\ldots$ & $\ldots$ & $\ldots$ & $\begin{array}{l}\text { Sheffield } \\
\text { Cambridge }\end{array}$ one seat \\
\hline$\underset{\mathrm{E}}{\mathrm{D}}$ & $\begin{array}{l}\ldots \\
\cdots \\
\ldots\end{array}$ & $\begin{array}{l}\cdots \\
\cdots\end{array}$ & $\begin{array}{l}\ldots \\
\ldots\end{array}$ & $\begin{array}{l}\ldots \\
\ldots\end{array}$ & $\begin{array}{l}\text { London, two seats } \\
\text { Oxford (including Wessex), } \\
\text { one seat }\end{array}$ \\
\hline $\mathrm{F}$ & $\cdots$ & $\cdots$ & $\cdots$ & $\cdots$ & $\left\{\begin{array}{c}\text { Bristol } \\
\text { Wales }\end{array}\right\}$ one seat \\
\hline G & $\ldots$ & $\ldots$ & $\ldots$ & $\ldots$ & Birmingham, one seat \\
\hline $\mathrm{H}$ & $\ldots$ & $\ldots$ & $\ldots$ & $\ldots$ & Manchester Me seat \\
\hline
\end{tabular}

All public health medical officers who are members of the B.M.A. and who devote five sessions or more per week (or the equivalent) to public health work with one or more local authorities are eligible to participate in the election. Nominations must be completed and returned to me not later than 6 September 1965. Both the member making the nomination and the candidate for election must carry out their public health duties within the region for which the nomination is made.

The above information together with a nomination form has been sent to public health medical officers who are members of the British Medical Association. Those who have not received a letter and consider that they are eligible and wish to participate in the election should send me their name and address without delay.

D. P. STEVENSON, Secretary.
Proposed Change in the Areas of the Bristol Division and the Somerset Division

Notice is hereby given by the Council to all concerned of a proposal to transfer the civil parishes of Baltonsborough, Butleigh, and West Pennard in the rural district of Wells from the area of the Bristol Division to the area of the Somerset Division.

Any member affected by this proposal and objecting thereto is requested to write to the Secretary of the Association by 18 September 1965.

\section{P. Stevenson,} Secretary.

\section{Diary of Central Meetings}

SEPTEMBER

2 Thurs. Joint Formulary Committee, 10.30 a.m.

Fri. Chest Clinics Subcommittee (C.C. and S. Committee), 10 a.m.

3 Fri. Dental Formulary Committee, 2 p.m.

7 Tues. Planning Subcommittee (Joint Consultants Committee),

Tues. Plining.

7 Tues. Joint Consultants Committee, 2.30 p.m.

7 Tues. Joint Consultants Committee, 2.30 p.m. Committee), 10.30

15 Wed Constitution Committee, 9.15 a.m.

15 Wed. Constitution Committee, 9.15 a.m.

Branch and Division Meetings to be Held

Notringham Division.-At 64 St. James's Street, Tuesday, 24 August, 8 p.m., meeting.

Correction-The Rochester, Chatham, and Gillingham Division's motion (No. 249) in the agenda of the Annual Representative Meeting, Swansea under the heading "General Practitioners and the Hospital Service," was moved at the Meeung by Dr. J. Ruffell (a deputy acting representative) and not Dr. J. M. Corall, as reported in the Supplement (17 July, p. 62). 